\title{
Institutional Audit of Pediatric and Adolescent Malignancy in Nepal
}

\author{
Krishna Sagar Sharma ${ }^{1}$, Sabita Panthi ${ }^{1}$, Kishor Pradhananga ${ }^{1}$, Bhaktaman Shrestha ${ }^{2}$ \\ ${ }^{1}$ B. P. Koirala Memorial Cancer Hospital, Chitwan, Nepal \\ ${ }^{2}$ NPI Narayani Samudayik Hospital, Chitwan
}

\begin{abstract}
:
Background: There have been no records of the incidence of pediatric malignancy recorded in Nepal until recently. The aim of this study is to analyze the cases of pediatric malignancy reported in 2006 in order to find out the relative frequency and geographical distribution of childhood malignancy throughout Nepal.
\end{abstract}

Methods: All the data for 2006 were collected from the Hospital-based Cancer Registry of Nepal (B P Koirala Memorial Cancer Hospital Registry Programme). All the cases included in the report were analyzed for geographical distribution, age, sex and relative frequency of the various types of childhood malignancies. The cancers were all classified according to the International Classification of Childhood Cancer (ICCC) and separated into 12 major groupings.

Result: A total 343 children and adolescents from seven tertiary care hospitals located in the western, middle and eastern regions of Nepal were registered in the Hospital-based Cancer Registry Program of Nepal. A majority of the patients were from the eastern and mid-eastern regions. The others were from the western, far-western and mid-western regions. Very few of them were from the far-western and mid-western regions. The males had a higher reported rate of malignancies than the females, $60 \%$ vs. $40 \%$. The adolescent population (13-19 years old) had $43 \%$ of the malignancies: a significant number. Leukemia (33\%), lymphoma (18\%) and bone tumors (13\%) were the first, second and third most common cancers among the 12 groups. The number of reported cases has increased each year from 2003 to 2006.

Discussion: The Hospital-based Cancer Registry was started in 2003. At that time not much attention was given during the collection of data to making note of the different variables. The incidence of pediatric malignancies has not been known till now. This study shows that the relative frequencies of pediatric malignancies and leukemia are the same as in western countries. Knowledge of the national incidence is necessary in order to make proper policies for the treatment of children with cancer and for research in the field of pediatric oncology. Brain tumors are the second most common cancer in developed countries but in our study it is the fifth most common malignancy: $20 \%$ Vs $5 \%$. We have a higher percentage of bone tumors $10 \%$ vs. $5 \%$ unlike other developed countries where population based registry data are available.

Key Words: Hospital-based Cancer Registry, Childhood Malignancy, geographical distribution, International Classification of Childhood Cancer (ICCC).

\section{Introduction}

Nepal is a mountainous land-locked developing country in South East Asia between India and China. It has a population of 22,736, 93 ${ }^{41}$. Nepal had no cancer institute or modern treatment facilities till 1999, when B. P.
Koirala Memorial Cancer Hospital (National Cancer Institute run by the government of Nepal) started its services in $1999^{2}$. Due to a lack of qualified manpower the National Cancer Institute could not start a pediatric and adolescent division till 2006 ${ }^{3}$. Nepal has 11,337,589

Correspondence

Dr. Krishna Sagar Sharma, Consultant and Head, Department of Medical Oncology,

B. P. Koirala Memorial Cancer Hospital, Bharatpur, Chitwan, Nepal; E-mail: akrish630@gmail.com 
children and adolescents younger than 20 years old. ${ }^{1}$ This population represents $49.86 \%$ of the population. B. P. Koirala Memorial Cancer Hospital (BPKMCH) started a hospital-based cancer registry with the support of World Health Organization (WHO). It included seven major tertiary care hospitals in Nepal where diagnostic facilities including pathology service have been available since 2003. Since there was no valid data available regarding the incidences or occurrences in Nepal, we decided to analyze the 2006 data available from the Hospital-based Cancer Registry program of B. P. Koirala Memorial Cancer Hospital to determine the incidence of cancer in the pediatric and adolescent population in Nepal.

\section{Materials And Methods}

All the cases of newly diagnosed cancers in 2006 were coded according to the International Classification of Disease of Oncology (ICD-0-2) and then grouped by ICCC $-2 .{ }^{15}$ A total of 343 cases of newly diagnosed cancers were recorded from the seven different tertiary care hospitals in Nepal included in the Hospital-based Cancer Registry of Nepal. The records were analyzed and categorized according to the geographical distribution of Nepal into regions, zones and districts. Males and females were categorized to find out whether the incidence of disease was different by sex. The patients were divided into three groups: 0 to 5 years, 6 to 12 years and 13 to 19 years to find out the age specific incidence of the diseases. Diagnoses of diseases were given names according to the ICD-0-2 and grouped according to the ICCC- 2 system. We estimated the incidence of childhood and adolescent malignancies using the data from the year 2006.

\section{Results}

The number of newly diagnosed pediatric and adolescent patients in the years 2003, 2004, 2005 and 2006 was 213, 261, 273 and 343 respectively. These records showed us that the numbers of pediatric and adolescent malignancies were increasing steadily. Among the 343 cases in 2006, all were diagnosed and pathologically proven in tertiary care hospitals. The highest number of cases was reported from BPKMCH (46.35\%), which shows its national importance as a National Cancer Centre (Table-1).

Table 1 : Distribution of Patients by Center and Sex

\begin{tabular}{|l|l|l|l|l|}
\hline \multicolumn{1}{|c|}{ Tertiary Care Hospitals } & \multicolumn{1}{|c|}{$\begin{array}{c}\text { Total Patients } \\
\text { by Hospital and } \\
\text { Percentage }\end{array}$} & Male & Female & \multicolumn{1}{c|}{ Status/Region } \\
\hline BPKMC Hospital Chitwan & $\begin{array}{l}159 \\
(46.35 \%)\end{array}$ & 100 & 59 & $\begin{array}{l}\text { National Cancer Institute } \\
\text { Mid-Nepal }\end{array}$ \\
\hline $\begin{array}{l}\text { BPKIHS, } \\
\text { Dharan, Sunsari }\end{array}$ & $\begin{array}{l}69 \\
(20.10 \%)\end{array}$ & 43 & 26 & $\begin{array}{l}\text { Deemed Medical University } \\
\text { Eastern-Nepal }\end{array}$ \\
\hline $\begin{array}{l}\text { Kanti Children's Hospital } \\
\text { Kathmandu }\end{array}$ & $\begin{array}{l}35 \\
(10.20 \%)\end{array}$ & 32 & 26 & $\begin{array}{l}\text { Pediatric Government Central } \\
\text { Hospital, Mid-Nepal }\end{array}$ \\
\hline $\begin{array}{l}\text { B. Cancer Hospital Bhaktapur } \\
(16.91 \%)\end{array}$ & $\begin{array}{l}14 \\
(4.08 \%)\end{array}$ & 5 & 9 & $\begin{array}{l}\text { NGO Cancer Hospital } \\
\text { Mid-Nepal }\end{array}$ \\
\hline $\begin{array}{l}\text { Bir Hospital } \\
\text { Kathmandu }\end{array}$ & $0(0.0 \%)$ & 0 & 0 & $\begin{array}{l}\text { NAMS Medical University } \\
\text { Mid-Nepal }\end{array}$ \\
\hline $\begin{array}{l}\text { T.U.T.H. } \\
\text { Kathmandu }\end{array}$ & $8(2.33 \%)$ & 5 & $\begin{array}{l}\text { Institute of Medicine } \\
\text { Mid-Nepal }\end{array}$ \\
\hline $\begin{array}{l}\text { Manipal Teaching Hospital, } \\
\text { Kaski, Pokhara }\end{array}$ & $\begin{array}{l}\text { Unity Teaching Hospital } \\
\text { Western-Nepal }\end{array}$ \\
\hline Total-Number Percentage & $\begin{array}{l}343 \\
(100 \%)\end{array}$ & $\begin{array}{l}206 \\
60 \%\end{array}$ & $\begin{array}{l}137 \\
40 \%\end{array}$ & \\
\hline
\end{tabular}


Patients from all five regional areas and 14 zones were recorded in the registry so it is a representative sample of Nepal. It covered 57 out of the 75 districts in Nepal (18 districts had no cancer cases registered) and shows us that malignancies were found in every part of Nepal. The incidence of cancer found in eastern, central, western, mid western and far western regions were $35.54 \%$, $39.75 \%, 18.07 \%, 4.81 \%$ and $1.80 \%$ respectively (Table-2).

Table 2: Distribution of Patients in 2006 by Regions and Zones

\begin{tabular}{|c|c|c|c|c|c|}
\hline Region & Zone & $\begin{array}{c}\text { No. of } \\
\text { Patients }\end{array}$ & Total & Percentage & $\begin{array}{c}\text { Districts with no Patients } \\
\text { Registered }\end{array}$ \\
\hline \multirow[t]{3}{*}{ Eastern } & Mechi & 27 & 118 & $35.54 \%$ & \multirow[t]{3}{*}{ Khotang } \\
\hline & Koshi & 65 & & & \\
\hline & Sagarmatha & 26 & & & \\
\hline \multirow[t]{3}{*}{ Mid } & Janakpur & 42 & 132 & $39.75 \%$ & \multirow[t]{3}{*}{ Rasuwa } \\
\hline & Bagmati & 57 & & & \\
\hline & Narayani & 33 & & & \\
\hline \multirow[t]{3}{*}{ Western } & Gandaki & 32 & 60 & $18.07 \%$ & \multirow{3}{*}{$\begin{array}{l}\text { Manang, Magdi, Mustang, Gulmi, } \\
\text { Arghakhanchi }\end{array}$} \\
\hline & Dhaulagiri & 5 & & & \\
\hline & Lumbini & 23 & & & \\
\hline \multirow[t]{3}{*}{ Mid Western } & Bheri & 7 & 16 & $4.81 \%$ & \multirow[t]{3}{*}{ Pyuthan,Humla, Dolpa, Jajarkot } \\
\hline & Rapti & 7 & & & \\
\hline & Karnali & 2 & & & \\
\hline \multirow[t]{2}{*}{ Far Western } & Seti & 3 & 6 & $1.80 \%$ & \multirow{2}{*}{$\begin{array}{l}\text { Doti, Asam, Bajura, Baitadi, } \\
\text { Dadeldhura, Bajhang, Darchula }\end{array}$} \\
\hline & Mahakali & 3 & & & \\
\hline Others & & 11 & 11 & $3.2 \%$ & Not specified district/zone \\
\hline
\end{tabular}

The Zonal-wise distribution of cases shows there were cases from all 14 zonal regions in Nepal. The Districtwise distribution of cancer shows that districts from the western region showed few or no reported cases. The decreasing number of reported cases of cancer from the east to west part of Nepal (Figure-1) may be due to the lower density of population, little awareness about childhood cancer and lack of diagnostic and treatment facilities in this part of Nepal.

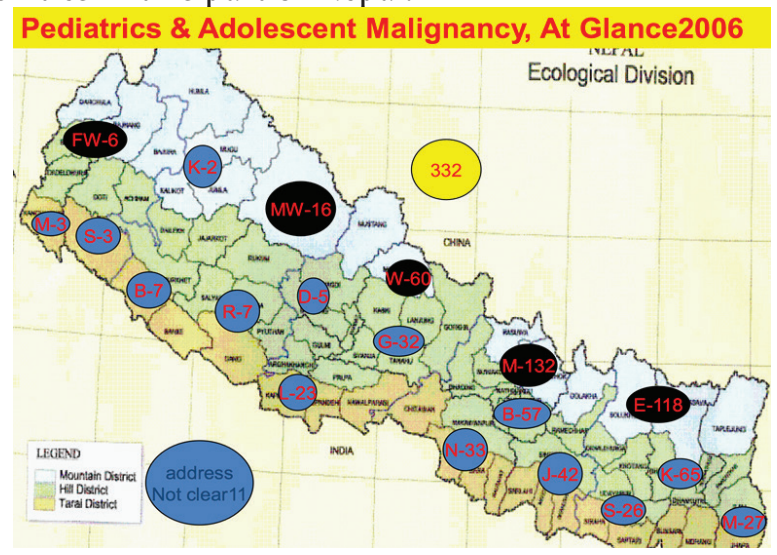

Figure 1: Geographical Distribution of Childhood Malignancies in Nepal in 2006.
(Abbreviations used above are - M-Mechi, K -Koshi, S-Sagarmatha, J-Janakpur, B-Bagmati, N-Narayani, G-Gandaki, D-Dhaulagiri, L-Lumbini, R-Rapti, B-Bheri, K-Karnali, S-Seti, M-Mahakali: E-Eastern Region, M-Mid Region, W-Western Region, MW-Mid western region, FW-Far western region).

According to the age distribution children and adolescents from all age groups showed cancer. There is a slight increase in the incidence of adolescent patients. It shows percentage of patients between 0 to 5 years, 6 to 12 years and 13 to 19 years; $23.32 \%, 33.52 \%$ and $43.14 \%$ respectively. There were significantly more male children reported and registered in the cancer registry, i.e. $60 \%$ Vs $40 \%$.

According to the ICCC-2 grouping, leukemia, lymphomas, bone tumors, soft tissue tumors and CNS tumors were the top five most common malignancies: $32.65 \%, 17.20 \% 9.62 \% 7 \%$ and $5.83 \%$ respectively. Retinoblastoma, germ cell tumors, nephroblastoma, head and neck malignancies, gastrointestinal malignancies were the next most commonly diagnosed malignancies in children less than 20 years of age (Table-3). 
Table 3 Diagnoses of Child and Adolescent Malignancy in Nepal in 2006

\begin{tabular}{|l|l|l|l|}
\hline $\begin{array}{l}\text { ICCC } \\
\text { Group }\end{array}$ & Diagnosis (Neoplasms) & $\begin{array}{c}\text { No. of } \\
\text { Patients }\end{array}$ & Percentage \\
\hline I & Leukemia & 112 & $32.65 \%$ \\
\hline II & $\begin{array}{l}\text { Lymphoma and } \\
\text { Reticulo-endothelial }\end{array}$ & 59 & $17.20 \%$ \\
\hline III & CNS Misc, ICTs, ISTs & 19 & $5.53 \%$ \\
\hline IV & $\begin{array}{l}\text { Sympathetic Nervous } \\
\text { System Tumors }\end{array}$ & 1 & $0.3 \%$ \\
\hline V & Retinoblastoma & 17 & $4.95 \%$ \\
\hline VI & Renal Tumors & 14 & $4.08 \%$ \\
\hline VII & Hepatic tumors & 0 & $0 \%$ \\
\hline VIII & $\begin{array}{l}\text { Malignant bone } \\
\text { tumors }\end{array}$ & 33 & $9.62 \%$ \\
\hline IX & Soft Tissue Sarcomas & 24 & $7.00 \%$ \\
\hline X & $\begin{array}{l}\text { Germ cell, } \\
\text { Trophoblastic and } \\
\text { other Gonadal }\end{array}$ & 17 & $4.95 \%$ \\
\hline XI & $\begin{array}{l}\text { Carcinomas and other } \\
\text { Malignant Epithelial }\end{array}$ & 24 & $7.00 \%$ \\
\hline XII & $\begin{array}{l}\text { Other and Unspecified } \\
\text { Malignant }\end{array}$ & 23 & $6.70 \%$ \\
\hline
\end{tabular}

Note: CNS-Central nervous, ICT-Intra-cranial tumor, IST-Intra-spinal tumor, NST-Nervous system tumor

\section{Discussion}

There were 343 patients diagnosed in 2006. According to the recent national population census (2001), the total population of children and adolescents below 20 years is $11,337,589$. The data shows that the reported pediatric and adolescent malignancies are 29.28 per million. This is quite a low rate for reporting and detection of malignancy in comparison to the incidence rates in other developing and developed countries. It is almost $1 / 4$ th of the expected cases of cancer. According to IARC the total incidence rate is usually in the range of 70 to 160 per million children. The relative frequency of the various malignancies is comparable, with leukemia about onethird and lymphomas about one-fifth 6. In Shanghai there was an annual crude incidence of 129.0 per million in 2002 to 20055. In Hong Kong there was a rate of 144.3 per million from 1982 to 19917 . In USA the rate was 146 per million in 20028 and in Europe 141 per million between 1993 and 1997.9, 10,11 This shows that there are many undiagnosed patients who die suddenly without diagnosis. In Nepal the child mortality rate is also high: 56 per 1000 live births under 5 years of age. ${ }^{12}$ If we can detect and treat curable malignancies in children, it will help to decrease the child mortality rate in Nepal. It also shows that the hospital-based cancer registry programme in Nepal needs to be strengthened and extended to get the all cancer cases recorded and reported to the cancer registry programme. It is still difficult to get a population based cancer registry right now in Nepal, but we have to establish good networking among pediatric departments of many other medical colleges, regional and sub-regional hospitals, zonal hospitals and other private hospitals where childhood malignancies can be diagnosed. We have to get major hospitals to participate in the cancer registry programme and to centralize data collection and analysis in order to implement at the national level national cancer prevention, control and treatment strategies as well as research activities. There was a steady increase in the number of cases recorded in the cancer registry, which shows that people are gaining an increasing awareness of cancer, its diagnosis and treatment. Based on the international incidences we can expect that there are 3 to 4 times more children with cancer in Nepal that remain undiagnosed or unrecorded.

With regard to sex, the male cases reported outnumber the female ones by a ratio of 3 to 2. In Shanghai and Hong Kong there is no such difference. They reported 133 per million for males and 128 per million for females in $1997 .{ }^{5}$ It indicates that gender discrimination towards those seeking medical help still persists significantly in the various communities in Nepal.

Childhood cancers are more meaningfully grouped by histological type and primary site by using the recently developed international classification of childhood cancer (ICCC). ${ }^{15}$ There are a significant number of childhood cancers that we need to focus on treating immediately, with leukemia, lymphoma, bone and soft tissue tumors at the top respectively. As in other parts of the world leukemia is the most common malignancy in Nepal (Table-4).

For purpose of comparison, we have included the Wakiko A. et al study in Osaka, Japan ${ }^{13}$, the Jun Li et al USA study ${ }^{14}$, the Incidence of India (AIIMS, 2003), the 
Shanghai incidences and the incidence of Nepal in our

major malignancies among these countries. study. It is notable that there is not much difference in

Table 4: Comparative Incidence for Various Countries

\begin{tabular}{|l|l|l|l|l|l|}
\hline \multicolumn{1}{|c|}{ Diagnosis (Neoplasm) } & $\begin{array}{c}\text { Present Study } \\
\text { (Nepal) }\end{array}$ & $\begin{array}{l}\text { Incidence India } \\
\text { 2003 AIIMS }\end{array}$ & $\begin{array}{l}\text { Incidence Osaka } \\
\text { Japan 1975-1994 }\end{array}$ & $\begin{array}{l}\text { Incidence } \\
\text { Shanghai }\end{array}$ & $\begin{array}{c}\text { Incidence USA } \\
\text { 2001-2003 }\end{array}$ \\
\hline Leukemias & $32.65 \%$ & $23.8 \%$ & $30 \%$ & $34.5 \%$ & $26.35 \%$ \\
\hline Lymphomas and & $17.20 \%$ & $11.5 \%$ & $11 \%$ & & \\
\hline Reticulo-endothelial & $5.53 \%$ & $21 \%$ & $20.6 \%$ & $20.2 \%$ & $17.57 \%$ \\
\hline CNS Misc, ICTs, ISTs & $0.3 \%$ & $4.1 \%$ & $8.6 \%$ & $6.2 \%$ & $5.01 \%$ \\
\hline Sympathetic Nervous System & $4.95 \%$ & $17.2 \%$ & $3.5 \%$ & $2.1 \%$ & $1.81 \%$ \\
\hline Retinoblastoma & $4.08 \%$ & $3.3 \%$ & $3.5 \%$ & $2.5 \%$ & $3.99 \%$ \\
\hline Renal Tumors & $0 \%$ & Not reported & $2.5 \%$ & $1.1 \%$ & $1.16 \%$ \\
\hline Hepatic tumors & $9.62 \%$ & $3.3 \%$ & $3.7 \%$ & $6.1 \%$ & $5.39 \%$ \\
\hline Malignant bone tumors & $7.00 \%$ & $3.8 \%$ & $5.5 \%$ & $6.1 \%$ & $7.15 \%$ \\
\hline Soft Tissue Sarcomas & Not reported & $7.5 \%$ & $6.1 \%$ & $6.49 \%$ \\
\hline $\begin{array}{l}\text { Germ cell, Trophoblastic and } \\
\text { other Gonadal Tumors }\end{array}$ & $4.95 \%$ & Not reported & $1.8 \%$ & $5.9 \%$ & $10.15 \%$ \\
\hline $\begin{array}{l}\text { Carcinomas and other } \\
\text { Malignant Epithelial }\end{array}$ & $7.00 \%$ & $11.8 \%$ & $1.7 \%$ & $0.8 \%$ & $0.46 \%$ \\
\hline $\begin{array}{l}\text { Other and Unspecified } \\
\text { Malignant Tumors }\end{array}$ & $6.70 \%$ & & & & \\
\hline
\end{tabular}

The table shows that a smaller percentage of brain tumors and a higher percentage of bone tumors are reported in Nepal. We cannot conclude that the incidence rate of brain tumors is less and bone tumors is more until we strengthen the pediatric cancer registry and successfully launch the population based cancer registry programme. In Nepal modern diagnostic facilities like the CT and MRI are out of the reach of many people who are poor and live in villages. X-ray machines are relatively available in remote areas so bone tumors can be detected relatively more frequently. This may be just an incidental finding. In order to discover whether this is true of not, a population based cancer registry should be established that includes all the cancer cases in a wider area or the whole country.

\section{Acknowledgement}

I would like to acknowledge Mrs. Mina Baral (HA) of the Cancer Registry for data collection. Dr. A. Makimoto (MD) Head of Pediatric Oncology at the National Cancer Centre Hospital, Tokyo, Japan for his continuous encouragement and guidance in writing. Father Regis Ging, MM, a former university teacher of English in Japan from the Maryknoll Society in Ossining New York, USA, for editing of the manuscript.

\section{References}

1. Government of Nepal, Central Bureau of Statistics. National Population Census 2001

2. Annual Report of B. P. Koirala Memorial Cancer Hospital, Bharatpur, Chitawan, Nepal 2000.

3. B. P. Koirala Memorial Cancer Hospital, Bharatpur, Nepal, Annual Report, 2006 and 2007

4. Waterhouse J, Muir C, Shanmugaratnam K et al. Cancer Incidence in five Continents, Vol. 3. Lyon: IARC Scientific Publications 1976: 456.

5. Ping-Ping B, Ying Z, Chun F et al. Time Trends and Characteristics of Childhood Cancer among Children Aged 0-14 in Shanghai. Pediatric Blood Cancer 2009; 53:13-16.

6. Parkin DM, Krama rova E, Draper GJ et al. International Incidence of Childhood Cancer, 
Volume II. Lyon: IARC Scientific Publications 1998:144.

7. Li CK, Mang OW, Foo W. Epidemiology of Pediatric cancer in Hong Kong, 1982-1991, Hong Kong Cancer Registry. Hong Kong Med J 1999; 5:128-134.

8. Ries LAG, Eisner MP, Kosary CL et al. SEER Cancer Statistics Review, 1975-2002, National Cancer Institute. http://seer.cancer.-gov/csr/1975_2002/ 2008-06-20.

9. Li J, Thompson TD, Miller JW et al. Cancer Incidence among Children and Adolescents in the United States, 2001-2003. Pediatrics 2008;121: 1470-1477.

10. Kaatcsh P, Steliarove-Foucher E, Crocetti E et al. Time Trends of Cancer Incidence in European Children (1978-1997): Report from the Automated Childhood Cancer Information System project. European J Cancer 2006; 42:1961-1971.

11. Steliarove-Foucher E, Stiller CA, Peter K et al.
Geographical Patters and Time Trends of Cancer Incidence and Survival among Children and Adolescents in Europe since the 1970s (The ACCIS project): An epidemiological study. Lancet 2005; 364:2097-2105.

12. Government of Nepal, Ministry of Health, Child Health Division, Community Based Newborn Care Programme, Trainer Manual, 2009.

13. Wakiko Ajiki et al. Survival Rates of Childhood Cancer Patients in Osaka, Japan, Japanese Journal of Clinical Oncology 2004; 34(1) 50-54.

14. Jun $\mathrm{Li}$ et al. Cancer Incidence among Children and Adolescents in the United States, 2001-2003, Pediatrics 2008; 121; e1470-e1477.

15. Birth JM, Marsden HB. A Classification Scheme for Childhood Cancer. International Journal of Cancer 1987; 40:620-624. 